\title{
Food Security in Ethiopia: Review
}

\author{
Dagnaygebaw Goshme* \\ College of Agricultural Sciences department of Agricultural Economics, Bulehora University, Ethiopia
}

*Corresponding Author: Dagnaygebaw Goshme, College of Agricultural Sciences department of Agricultural Economics, Bulehora University, Ethiopia

\begin{abstract}
Achieving food security is development agenda for Ethiopia due to the presence of food insecure people in different parts of the country. Over 80 percent of Ethiopian population live in rural areas and are heavily dependent on rain-fed agriculture. Agricultural productivity of rural people is still low due to overuse of natural resources, climate change, and others that reduce per capita food production which is the challenge of the country. The paper review determinants of food security, cause of food insecurity and coping strategies practiced in Ethiopia. Annual income, livestock and land holding, livestock feed, fertilizer usage, access to veterinary and extension services, credit access, remittances, access to employment and oxen ownership positively affect food security while family size, livestock disease, dependency ratio, distance to market, age of the household head negatively affect food security. Environmental degradation, high population growth, diminishing land holdings, outbreak of plant and livestock disease, pests, chronic shortage of cash income, limited household assets, poor social and infrastructural facility, instability and armed conflicts, pre and post-harvest crop loss and lack of on-farm technological innovations, climate change, drought, flood, frost attack, lack of oxen, poor soil fertility, weak extension services, lack of employment opportunities, high labor wastage, corruption and political instability, lack of appropriate policies and institutions and the like are causes of food insecurity. sale of more livestock than usual, borrowing of food or cash, reduce number and size of meal, sale firewood and charcoal, seasonal migration, seeking alternative or additional job, rely on less preferred and less expensive food, seeking relief assistance, short term/seasonal migration, seeking alternatives or additional jobs, becoming temporary trade, household splitting, consume wild food, remittance, participating in cash basis project works, diversification of livelihood incomes, Purchasing of grains from market, Renting out land are some of coping strategies practiced in Ethiopia.
\end{abstract}

Keywords: Food Security, Food Insecurity, Determinants, Coping Strategies

\section{INTRODUCTION}

It is widely accepted that food is a basic necessity of life. Its importance at the household level is obvious as food is a basic means of sustenance. Adequate intake of quality food is a key requirement for healthy and productive life which indicates food security status of a household. A household is food secure if it can reliably gain access to food in sufficient quantity and quality for all household members to enjoy a healthy and active life [1].

Food security and nutrition is at the heart of Africa's development agenda with greater commitment to ending hunger, achieving food security and advancing optimal nutrition for all Africans [2]. Food insecurity, a complex and multi-faceted phenomenon, is currently one of the international community's main priorities, especially in sub-Saharan Africa. Food insecurity in this region is most widespread in pockets of extreme poverty, particularly in rural areas; traditional agricultural or general economic interventions alone are unlikely to generate substantial improvements [3].

Majority of poor people in developing country live in rural areas where their livelihood and food security are dependent on agriculture. Studies indicated that agricultural productivity of rural people in many developing countries is decreasing due to overuse of natural resources, climate change, among others. As a result, it is reported that low level of per capita food production is a common challenge of the countries. Thus achieving food security requires aggregate availability of physical food supplies, access to food supplies and utilization of food to meet the specific dietary needs of households or individuals in the households [4]. 
Climate change is likely to have adverse effect on the food security status of people especially those in the developing world and rely on agriculture for their livelihoods. Households who applied changing planting dates as strategy against climate change have high probability of being food secured [5]. Across central Ethiopia, early season dryness worsened in April; creating large rainfall deficits that damaged crop production and pasture development due to this an estimated 2.9 million people were in Crisis and Emergency [6].

In 2015, Ethiopia faced one of the most severe droughts in half a century due to the effects of El Niño. It experience between 50 and 90 percent crop loss and the livestock sector has seen extreme mortality and morbidity rates and abnormal migration in search of pasture and water. Many families dependent on agriculture have become indebted and dependent on humanitarian assistance. With inadequate sources of food and income as a result of the drought, vulnerable rural households face widespread hunger and malnutrition. In late 2015, a Government-led multi-agency me her assessment found that 10.2 million people were food insecure, while 2 million required agricultural input support to resume food production and also in 2016, FAO assist vulnerable families to restore agricultural production, regain their livelihoods and better withstand future crises for 1.8 million pastoralists, agro pastoralists and smallholder farmers affected by El Niño [7].

Government of Ethiopia has recently appealed to its international partners for emergency food assistance to feed 10.2 million people and for special nutritional programmers' for more than 2.1 million, including 400,000 severely malnourished children. In addition, over 8 million vulnerable and food-insecure people receive support under the Productive Safety Net Programmer [8]. The objectives of the review are; to review the determinants of food security, causes of food insecurity and coping strategies practiced in Ethiopia.

\section{DETERMinants OF FoOd SECURITY}

There are several factors that affect food security either positively or negatively. Different studies show the determinants of food security in various parts of Ethiopia. According to [9], determinants of food security conducted in Gode District, Shebelle Zone of Somali Regional State Ethiopia using binary logic model, family size, annual income, livestock holding, livestock disease, livestock feed, and dependency ratio are the major determinants of food security, from those family size, livestock disease and dependency ratio are negatively related to food security, while the remaining are positively related.

[10], using binary logic model, show that seven variables were significant determinants of household food insecurity. These were distance to nearest market center, dependency ratio, cultivated land, livestock ownership, oxen ownership, remittance and off-farm income from those distance to nearest market center and dependency ratio were positively related to food insecurity or negatively related to food security and the remaining are negatively and positively related respectively.

According to [11] Age of household head, family size and access to extension services had a negative effect on household food security status while household income, credit access, oxen ownership and cultivable land size had a positive effect on household food security.

According to studies conducted in Jigjig a District of Ethiopia, use of fertilizer by farming households, total household income, access to veterinary services and access to extension services was found to have a positive and significant impact on household food security; whereas, the agroecology stratum in which the households' farmland was located found to have a negative and statistically significant impact on food security [12].

[13], using binary logic model, sex and age of the household heads, dependency ratios, household size in adult equivalent, livestock ownership in tropical livestock unit, and fertilizer utilization were determinant factors for food security status. The study by using binary logic model indicated that household size and age of the household head have positive and significant effect on household food insecurity; whereas, educational status of the household head, asset possession, credit access and access to employment have negative effect [14].

According to [15] conducted in Jigjig a District of Ethiopia, use of fertilizer by farming households, total household income, access to veterinary service and access to extension service was found to have a positive and significant impact on house hold food security; whereas the agro ecology stratum 
in which the households farm land was located found to have a negative and significant effect on household food security.

The study by using binary logic model showed that dependency ratio and distance from nearest market were negatively and significantly related to house hold food security, on the other hand, age of the house hold head, educational statues of the house hold head, livestock holding in tropical livestock unit and frequency of extension contact were found to be positively and significantly related to the food security status of household [16].

[17] using multiple linear regression indicated that age of the household head, use of improved seed and adult equivalent have negative effect and statistically significant factor for food security; whereas, land size in hectare and number of livestock in tropical livestock unit positively affect food security of households. [18] Educational status of household head, family size, use of farm input and number of oxen owned by households were determinants of food security.

[19] Indicated in his study entitled on Food insecurity and coping strategies: a perspective from Kersa District, East Hararghe Ethiopia using binary logic model found that out of eleven significant variable six significant variables were thought to influence the food security status. Those variables that showed significance in the model were: age of the household head, sex of the household head, household size in Adult Equivalent, total cropping land, oxen owned and remittances in Birr. From this household size in adult equivalent and age of the household head affect food security negatively.

[20], in their study entitled on Empirical analysis of the determinants of rural household's food security in Southern Ethiopia in Shashemene District has shown that the major factors affecting food security of rural households were family size, total cultivated land size of household head, annual farm income, total cultivated land size, total off-farm income and livestock holding. Study also indicates that annual farm income; off farm income have a significant and positive influence on the state of household food security while family size and food security were negatively related.

According to [21] by using binary logic model different variables like family size, age of the household head, amount of fertilizer usage, market distance, annual off/non-farm income, total farm income and soil fertility problem were determinants of food security status.

\section{CAUSe OF FoOd InSECURITY In ETHIOPIA}

Several studies were conducted on causes of food insecurity in Ethiopia; some of those are the following. According to [22] a number of factors can explain the trend towards the increasing food insecurity situation in Ethiopia. The interaction between environmental degradation, high population growth, diminishing land holdings, outbreak of plant and livestock disease, chronic shortage of cash income, poor social and infrastructural facility, instability and armed conflicts, pre and post-harvest crop loss and lack of on-farm technological innovations led to a significant decline in the productivity per households and cause food insecurity and starvation. These trends have combined with the repeated effects of drought over years, to substantially erode the productive assets of rural households.

Food insecurity in Ethiopia is caused by population pressure, drought, shortage of farmland, lack of oxen, deterioration of food production capacity, outbreak of plant and animal disease, poor soil fertility, frost attack, shortage of cash income, poor farming technologies, weak extension services, high labor wastage, poor social and infrastructural facility and pre and post-harvest crop loss [23].

El Niño was expected to last at least until April/May 2016, exacerbating the food insecurity caused by the upcoming lean season. Over 15 million people are expected to be in need of humanitarian assistance in 2016. Poor households in affected areas in southern Afar and Sitti (former Shinile) Zone in Somali Region, in East and West Hararghe zones in Oromiya, and in Wag Hemra and North Wollo in Amhara region, are expected to remain in Emergency [24].

According to [25] Natural disasters such as drought and climate change, shortage of farm land, lack of functional multi-party democratic systems, land reform policy, lack of appropriate policies and institutions, lack of rural infrastructures, population growth and lack of education are the major causes of food insecurity in rural Ethiopia.

The majority of the severest food crises after the second half of the 20 century were caused by a combination of several factors. The most common causes of food insecurity in African and other third 
world countries were: drought and other extreme weather events, pests, livestock diseases and other agricultural problems, climate change, military conflicts, lack of emergency plans, corruption and political instability, cash crops dependence, aids and rapid population growth [26].

Ethiopia has relative political stability in Horn of Africa, however several areas are insecure. [24] Conflict and civil unrest is the major sources of food insecurity problems and lead to serious disaster in Ethiopia, by disturbing the country ongoing economic growth and development progress.

Climate change affects food availability through its increasingly adverse impacts on crop yields, fish stocks and animal health and productivity, especially in sub-Saharan Africa and South Asia, where most of today's food insecure live. It limits access to food through negative impacts on rural incomes and livelihoods. Smallholder farmers and agricultural workers are more vulnerable to the impacts of such disasters. Severe droughts or floods can sharply reduce incomes and cause asset losses that erode future income earning capacity. In addition, to the extent that food supply is reduced by climate change, food prices will increase [7].

The main causes of food insecurity are high population growth rate, high reliance on small-size and rain-fed agricultural holdings, lack of access to input, lack of access to credit, high susceptibility to drought, limited access to basic service, lack of access to market, land degradation and decreased productivity, lack of income generation opportunity and alternatives, lack of access to technology and lack of access to information on market, agricultural technology [27].

\section{Coping Strategies Practiced In EThiopia}

Households adopt and develop diversified coping strategies and sequential responses through which people used at times of decline in food availability. Different studies have been identified food insecurity coping mechanisms in Ethiopia some of those are reviewed the following manner.

To cope with these problems Ethiopian people use sale of livestock, agricultural employment, and migration to other areas, requesting grain loans, sales of wood or charcoal, small scale trading and limiting size and frequency of meal as major coping mechanisms [22].

According to [10] sale of more livestock than usual, borrowing of food, reduce number of meal, reduce size of meal, sale firewood and charcoal, seasonal migration, seeking alternative or additional job, rely on less preferred and less expensive food, seeking relief assistance, becoming temporary trade, household splitting, consume wild food, remittance, participating in cash basis project works were the common coping mechanisms practiced by households ho faced food insecurity problem.

According to [23], Sale of wood or charcoal, small scale trading, income transfer systems, limiting size and frequency of meal, sale of livestock, agricultural employment and migration were major coping strategies.

The rural dwellers of Ethiopian used different coping strategies so as to cope up with the existing food insecurity including reduction of number and quantity of meals per day; diversification of livelihood incomes, wage and migration. In addition to the coping mechanisms used by rural households the government of Ethiopia used different strategies to mitigate food insecurity in Ethiopia including food aid, implementation of productive safety net program and other food security reduction programs [25].

According to [28] on determinants of household food security and coping strategies: the case of BuleHora District, Borana Zone, Oromia, Ethiopia, farm households coping mechanisms in are reducing number and size of meal per day, Skipping and reducing food help intake, Purchasing of grains from market, renting out land, selling livestock, pity trading, working as a laborer and borrowing cash or grains from others. According to [11] limiting population pressure, promoting income-generating activities, enhancing micro financing efficiency, creating employment opportunities, information dissemination, and others can contribute to food security status of households in the study areas.

Work as a daily labor, received relief food aid, migrate to work, reduce the number of meals, sale of livestock, purchased food on cash, ate less preferred food, sold household possession, sale of fire wood, sold seed meant for planting, borrow food/money from relatives, and Children discontinued school were the main means of coping mechanism to fight food insecurity [29].

Accumulation of assets, reducing consumption, borrowing from others, building savings and seeking alternative sources of income and food are some of the copping strategies [5]. According to [30] food 
aid, borrowing cash or grain from relatives, sale of livestock, reducing frequency and amount of meals, remittance were coping strategies practiced by the food insecure households.

[31] Results revealed that important local strategies that were practiced by both food insecure and food secure households to cope with food insecurity. Those were purchase of food item on cash, sale of animals, borrowing from neighbors (relatives), stop sending children to school, income from off farm, selling charcoal, receiving gift of remittance, eat less food, selling other asset, out migration and relief food aid. [13] Also found that; reduction of meal, borrowing cash or grain, receiving food aid, working as a daily laborer, sale of livestock, fire wood, charcoal, wild grass (as a forage), and household assets, were coping strategies

\section{Conclusions}

Ethiopia is facing a massive drought and food insecurity crisis over the years. Drought, recurring food shortage and famine are great challenges faced by Ethiopian people. Different studies on current food security situation in the country show that there is a growing consensus that food insecurity, famine and poverty problems are closely related in the Ethiopian context in which drought and weather related shocks are the main driving forces. Food insecurity is an enduring, critical challenge in Ethiopia which is Africa's second populous country after Nigeria. Over 80 percent of Ethiopian population live in rural areas and are heavily dependent on rain-fed agriculture; this makes them extremely vulnerable to changes in weather conditions that led to drought and finally become food insecurity condition.

The causes of food insecurity are many and interlinked each other and vary from place to place. The major causes of food insecurity in the country includes environmental degradation, high population growth, diminishing land holdings (shortage of farmland), outbreak of plant and livestock disease, pests, chronic shortage of cash income, limited household assets, poor social and infrastructural facility, instability and armed conflicts, pre and post-harvest crop loss and lack of on-farm technological innovations, climate change, drought, flood, frost attack, lack of oxen, poor soil fertility, weak extension services, lack of employment opportunities, high labor wastage, corruption and political instability, lack of appropriate policies and institutions, and etc. due to one or more than one of the above causes people face food security problem in the country.

The rural people of Ethiopian used different coping strategies so as to cope up with the existing food insecurity including sale of more livestock than usual, borrowing of food or cash, reduce number of meal, reduce size of meal, sale firewood and charcoal, seasonal migration, seeking alternative or additional job (agricultural employment), rely on less preferred and less expensive food, seeking relief assistance, short term/seasonal migration, seeking alternatives or additional jobs, becoming temporary trade, household splitting, consume wild food, remittance, participating in cash basis project works , diversification of livelihood incomes, Purchasing of grains from market, Renting out land and etc.

To improve food security, the following action should be taken. Develop different income generating activities, applying different research outputs, adoption of technologies, income diversifications, creating employment opportunities and use of other coping mechanisms.

\section{REFERENCES}

[1] Maxwell S, Frankekberger T. (1992). Household food security: Concepts indicators, measurement. A Technical Review. UNICEF/IFAD.

[2] FAO (Food and Agricultural Organization). (2017). Regional Overview of Food Security and Nutrition in Africa. The challenges of building resilience to shocks and stresses. Accra.

[3] Francesco B, Margherita S, and Giorgio A.(2016). Addressing food insecurity in sub-Saharan Africa: the role of cash transfers. Discussion Paper / Deutsches Institute für Entwicklungspolitik ISSN 1860-0441

[4] Asogwa B, Umeh J. (2012). Food Insecurity Determinants among Rural Farm Households in Nigeria. International Conference on Ecology, Agriculture and Chemical Engineering (ICEACS'2012) December 18-19, 2012 Phuket (Thailand).

[5] Lemma Z. \& Wondimagegn M. (2014).Smallholders' Vulnerability to Food Insecurity and Coping Strategies: In the face of climate change, East Hararghe, Ethiopia. Journal of Economics and Sustainable Development www.iiste.org, Vol.5, No.24 
[6] WFP (World Food Program). (2015). Tracking food security trends in vulnerable countries. Global Food Security Update, Issue 18.

[7] FAO (Food and Agricultural Organization). (2016). Climate Change, Agriculture and Food Security. Rome, Italy.

[8] Nkunzimana T., Custodio E., Thomas A.C., Tefera N., Perez Hoyos A., Kayitakire F. (2016). Global analysis of food and nutrition security situation in food crisis hotspots; EUR 27879; doi:10.2788/669159

[9] Taye T. (2014). Determinants of food security of pastoral and agro pastoral households: the case of Gode district, Shebelle zone of Somali regional state Ethiopia. MSc thesis presented to school of graduate studies of Haramaya University.

[10] Abdirahman A. (2015). Food Insecurity and Coping Strategies of Agro-Pastoral Households in Babile District of Somali Regional State, Ethiopia. Msc Thesis, Haramaya University, Haramaya.

[11] Tekle L. and Birhanu K. (2015). Determinants of Rural Farm Household Food Security in Boloso Sore District of Wolaita Zone in Ethiopia. Asian Journal of Agricultural Extension, Economics \& Sociology, 5(2): 57-68.

[12] Wali H. and Pen porn J. (2013). Determinants of rural household food security in Jigjig a District of Ethiopia. Kasetsart J. (soc.sci), 34: 171-180.

[13] Meseret M. (2012) Household Food Security Status and Coping Strategies in Humbo Wereda, SNNPRS, Ethiopia. International Journal of Sciences: Basic and Applied Research, Volume 6, No 1: pp 64-82.

[14] Girma G. (2012). Determinants of Food Insecurity among Households in Addis Ababa City, Ethiopia. Aksum University, Ethiopia, Addis Ababa.

[15] Hussien W and P.Janekarnkij.(2013).Determinants of Rural Household Food Security in Jigjig a District, of Ethiopia. KasetsartJ.(Sos.Sci), 34:171-180

[16] Eshetu D. (2013). Factors affecting household food security: the case of Abichu-Gnea district, North Shewa zone, Oromia national regional state, Ethiopia. MSc thesis presented to school of graduate studies of Haramaya University.

[17] Kahsay.S and Mulgeta.M. (2014). Determinants of Rural Household Food Insecurity iln Laelay Maichew Woreda Tigray, Ethiopia. Afr.J.Agric.Food Secur., 2: 106-112.

[18] Mequanent M, Birara E and Tesfalem K. (2014). Determinants of Household Food Security among Southwest Ethiopia Rural Households. Food Science and Technology, 2(7): 93-100.

[19] Sisay B. (2012). Food insecurity and copping strategies: a perspective from Kersa district, East Hararghe Ethiopia. Food Science and Quality Management www.iiste.org ISSN 2224-6088 (Paper) ISSN 2225-0557 (Online), Vol 5, 2012.

[20] Amsalu M and Beyene T. (2012). Empirical analysis of the determinants of rural household's food security in Southern Ethiopia: The case of Shashemene District. Basic Research Journal of Agricultural Science and Review ISSN 2315-6880 Vol. 1(6) pp. 132-138.

[21] Yilma M.(2005).Measuring Rural Household Food Security Status and its Determinants in the Benshangul Gumuz Region, Assosa Woreda, Ethiopia. Msc thesis, haramaya university, Ethiopia.

[22] Abduselam A. (2017). Food Security Situation in Ethiopia: A Review Study. International Journal of Health Economics and Policy, 2(3): pp. 86-96.

[23] Birara E, Mequanent M and Samuel T, (2015). Assessment of Food Security Situation in Ethiopia: A Review. Asian Journal of Agricultural Research, 9: 55-68.

[24] UNICEF (United Nations Children's International Children's Emergency Fund). (2015). “Humanitarian appeal report". Addis Ababa, Ethiopia.

[25] Yenesew S. (2015). Causes and coping mechanisms of food insecurity in rural Ethiopia, 123-133. https://doi.org/10.5251/abjna.2015.6.5.123.133.

[26] AFI (Amagansett Food Institute). (2012). Causes of Food Insecurity in African and Other Third World Countries.

[27] EU (European Union). (2012). Effectiveness of European Union development aid for food security in SubSaharan Africa.

[28] Ahmed M. (2015). Determinants of household food security and coping strategies: the case of bule-hora district, borana zone, oromia, Ethiopia, European Journal of Food Science and Technology Vol.3, No.3, pp.30-44.

[29] Misgina A. (2014). Rural household food security status and its determinants : The case of Laelaymychew Woreda, Central Zone of Tigray, Ethiopia, 
[30] Sadik A. (2012). Magnitude and determinants of food insecurity among agro pastoral households in Jigiga districts, Somali regional state, Ethiopia. MSc thesis presented to school of graduate studies of Haramaya University.

[31] Tesfaye K. (2013). Determinants of rural household food insecurity and identifying their coping strategies in Somali region of Ethiopia: the case of Gursum district. MSc thesis presented to school of graduate studies of Haramaya University.

Citation: Dagnaygebaw Goshme, (2019). "Food Security in Ethiopia: Review” International Journal of Research Studies in Agricultural Sciences (IJRSAS), 5(1), pp.1-7, http://dx.doi.org/10.20431/24546224.0501001

Copyright: (C) 2019 Authors. This is an open-access article distributed under the terms of the Creative Commons Attribution License, which permits unrestricted use, distribution, and reproduction in any medium, provided the original author and source are credited. 